\title{
SUGAR-CANE CULTIVATION
}

By F. S. EArLe, Agronomist, Central Aguirle

Sugar-cane agriculture in the West Indies is fifty years behind the manufacturing side of the industry. It is hard to understand why this should be so, but no one conversant with the facts will dispute it. Nothing is more urgently needed than to bring the work in our cane fields into accord with the farm practices long recognized as indispensable in the growing of other similar crops. Sugar cane, in order to produce a maximum yield, requires a heavier rainfall or a more abundant supply of irrigation water than is needed for most. crops, and it needs it, too, for a longer period. Now the only known way to supplant rainfall and to conserve soil moisture is by giving frequent surface tillage to form and preserve a dust mulch. This has been thoroughly understood for many ycars and it is the regular practice with all similar erops. Why not with sugar cane, which needs it even more? In the corn belt no one thinks of planting corn without giving it constant cultivation. Even as droutliresistant a plant as cotton is cultivated most carefully. In Lonisiana cane is cultivated like a corn field. It is only liere in the West Indies, on the hardest and most compact soils and with the most capricious of rainfalls, that we expect cane to grow and yield full crops year after year without this fundamentally necessary assistance. Our present methods have come down to us from the times when cane was planted on new lands-freshly cut-over timber lands. No special cultivation was needed then, nor is it needed today on such new lands. The humus which they contain so abundantly holds moisture and the decaying rootlets leave the ground porous and well acrated. All this changes with age as the soils become hard and compact, when this porousness and permeability to air, so necessary for plant growth, has to be restored by tillage. The roots of sugar cane are very susceptible to lack of air. When the soil becomes enerusted they quickly suffer and are apt to be attacked by the fungi causing "root disease", a condition causing more losses to cane on old lands than all of the other cane troubles combined. It is "root disease" that has coused so many of the old standard varieties to fail as the land becomes more hard and compact through ecntinued cropping and the loss of regetable matter. In one country 
after another first Otaheite and the Rayada and Cristalina have gone down and been abandoned on account of "root diseases." This trouble has caused the loss of untold thousands of dollars in all parts of the sugar-cane growing world, and yet it is easily controlled. Three things are required, and of these each is as important as the other: first, proper drainage; second, abundant fertilizing, and third, frequent tillage. Used with good judgment and common sense these three things will prevent nineteen-twentieths: yes, ninety-nine hundred of the cases of root disease, and at the same time will so increase yields that they will prove a decided cconomy and not an expense.

Nore tillage, then, is a necessity if we are to seeure full yields of came on old lands, first, to conserve moisture and, second, to aerate the soil so that the roots may be supplied with oxygen, for they are living things and, like everything else which has life, they take in oxygen and give off carbonic-acid gas. When the soil is hard and encrusted this necessary exchange of gases is impeded and the vitality of the plant suffers. Anything which lowers the vitality of the cane plant permits the attacks of the root-killing fungi. Again, the presence of oxygen in the soil is necessary for the growtin of those soil bacteria that are instrumental in transforming the crude plant food contained in the soil inte nitrates and other forms in which it is availalle for growth. In badly aerated soils another set of organisms develop which destroy these nitrates and thus rob the soil of its fertility. Some recent investigators have gone so far as to claim that this effect of tillage in rendering the plant food in the scil more available is the real reason for its beneficial effect during period of drouth. The soil solution is made richer in plant food and so less of it is required to keep the plant in active growth. Be this as it may, the outstanding fact remains that frequent shallow tillage during dry weather aids remarkably in keeping crops in active, vigorous growth. Why, then, do not eane planters. like other farmers, take advantage of this long-known and well. established fact? The only answer is that they are still blindly following the customs of their fathers: customs sufficiently well adapted to the fresh new lands of those times, but not adapted to the compacted and partially exhausted lands of today.

By tillage is meant any stirring of the surface soil between growing plants with implements. This may, of course, be done by hand with the hoe or rake. The surface scraping usually done with 
the hoe in Porto Rico can hardly be called tillage since it does not brake the surface crust. Usually it is more cheaply and effectively done by implements drawn by animal power. Mules and horses are better adapted to this work than oxen and usually their work is much cheaper. Tillage by tractors is surely coming in the near future, but so far it has hardly passed the experimental stage. The kind of implement to use for eultivation will depend on the system of planting adopted and to some extent on the nature and condition of the soil. The more generally useful tools are the 5 -shovel cultivator, the 13-tooth harrow cultivator, the double shovel, the single shovel or Georgia stock with its various attachments and the small 7 -inch turning plow. First one and then another of these implements shonld be used according to the condition of the land and the amount of weed growth. The small reversible dise harrow with only six dises is often very useful, especially when the land was crudely prearad. The straddle-row riding cultivators had best not be attempted until after our labor becomes accustomed to handling these simple instruments. When properly handled these implements, working as they do on both sides of the row at once, are great savers of time.

There are three principal systems of eane planting in use in Porto Rico. Each will require special methods of eultivation in order to secure best results. The inrigated lands are mostly planted on the Hawaiian, system, first successfully introduced by the late Patrick MacLain when he was Administrator of Central Aguirre. In this method the cane is planted at the bottom of deep furrows which are laid out as nearly as possible on the level grade lines. These planting furrows are crossed at intervals of thirty to forty feet by light furrows for bringing in the water. This secures a more uniform distribution of water than is possible with the old system of ruming the rows with the grade and allowing the water to follow them for considerable distances. Having to maintain the banks between the rows to confine the water makes tillage more difficult than where level eulture is possible. This has been made an excuse for doing little or no enltivation on the irrigated lands of the southern coast where the tendency has been to depend on irrigation water alone to make the crop. This is a serious mistake, especially in the ratoon fields. Much better results will follow if each irrigation is followed within a few days by a cultivation to break the erust and restore a dust mulch. From 20 per cent to 25 
per cent less water will be required and better erops will be secured. For this cultivation it is best to alternate, using filst the harrow-cultivator held at an incline first on one side of the lank and then the other. This implement tends to pull down the banks and after using it a few times the 5-tooth cultivator should be substituted for it, putting on the broad hilling-up wings that come with it and taking off the three forward shovels. The wings should be set to turn the dust toward the middle and the width shonld be adjusted to fit the bank. This will restore the central ridge to hold in the irrigation water. The single shovel or Georgia stock with a 16-inch "heel sweep" may now be ned between this central ridge or bank and the cane to dean out and open up the water furrow. By the alternate use of these three cheap and simple implements irrigated cane may be cultivated easily and effectively. Simply fol'ow every irrigation or rain by a cultivation. That is an easy rule to remember.

Dry uplands that are unirrigated and where no extensive drainage is required are best planted on what may be called the Cuban system, since it is employed so widely in that island. The cane is planted in deep furrows as for irrigation but, it is usual to run through with enough slope to carry off an excess of rainfall. These furrows are gradually filled in by the enltivation and when the cane is laid by the ground should be nearly level. This is the simplest kind of eane enltivation. The seed shonld be placed in a single continnous line in the bottom of the furrow-not in a double line nor in wide "holes" with spaces between, for this leaves space that recuires hor work. Any of the above-mentioned implements may be used with this system of planting. If done frequently enough to destroy the grass and weeds as they are sprouting, the 13-tooth harrow-enltivator will be the only implement needed, and, if care is taken each time to run close to the cane, almost no hoe work will be required. If continued rains do not permit cultivation and the cane gets grassy it will be necessary to use eitlue the double shovel or the small tuming plow, but these implements should be followed closely by the harrow-eultivator. It will pay to run the cultivators as often as every ten days, or in some cases even oftener. Always cultivate as soon as possible after a heavy rain. Remember you are not enltivating primarily to kill weeds but to aerate the soil. Weed killing is a useful secondary benefit.

All wet lands that require drainage should be planted on the 
Porto Rican gran banco system. Many Porto Rican cane lands are of this nature and this system has been developed here locally to neet these conditions to which it is admirably adapted. In Lonisiana cane is also planted on low, wet lands. There they meet this condition by planting on top of sharp single-row ridges. The land is prepared much as for planting according to the Cuban system, but the cane is planted on top of the bank and not in the furrow, which is kept open for drainage. This Louisiana system would not be well adapted to Porto Rico since here cane even on wet lands sometimes suffers from drouth and these narrow ridges would dry out unduly. The Porto Rican gran banco, wide enough for two cane rows, do not dry out so quickly. When laborously made by hand with the shovel, which is still the usual practice, they are very expensive. In most cases there is no need at all for this and it is a custom which shonlt be immediately abandoned. No eonceivable "protection duty" will serve to make cane growing permanently profitable if such expensive practices are followed. Most of these wet lands are dry enough at some season of the year to admit of preparation witl the plow. They should be prepared at such times. Deep plowing is not required but the surface should be well pulverized by several harrowings. Then lay off the banks with a big turning plow giving two ents in the same furrow, and removing as deep as possible. Clean the furrow either with the big double mould loard (bombo) or with the Martin grader or with both, and the banks are made. Open a light furrow on either side of the bank with a 7 -inch turning plow as a guide in planting and plant in a single line (chorro). Do not destroy the bank by making a deep furrow for planting and do not plant in loles for this makes your rows so wide that there is no space for cultivation. Cultivate on top of the hank with the harrow cultivator much as in the Cuban system. Before the ditehes get set with grass clean these with a pass of a medimn-sized double-monld-board plow. The one used in Cuba for opening planting furrows and there called a limpiator will be about right. This will keep the ditches clean much eheaper than it can be done by land. On very wet lands where there, is constant standing water in the ditches the above directions cannot always be carried out. In such eases it is usually better to make wide 20 -foot banks with deep permanent ditches between them. These will likely have to be made by hand and they should be carefully run in the direction to give best drainage. After the ditches are opened the land will soow dry enough so that the 
top of the bank can be prepared with a small 8 - or 10 -inch plow. There will be room for four rows and level cultivation can be given. This plan is working well in actual practice.

Whatever plan of planting is followed it is of great importance to put at least 400 pounds of fertilizer per acre in the planting furrow before planting. A second application can be given at the side of the cane row when it will be covered by the cultivation after the cane is two to three feet high. Sulsecunent applications, however. cannct take the place of this first one in the bottom of the planting furrow. This not only places it where it will be immediately available for the young roots as they form, thus insuring a vigorous early growth, but, by its deep application it induces a deep rooting habit that better enables the young plants to resist drouth. Applications made after planting are necessarily placed above the roots and the tendency is to induce a shallow root growth. The importance of this matter eannot be too strongly insisted upon, though it seems to be little understood in Porto Rico.

It is, however, in the ratoons that better cultivation is most urgently needed. With plant cane the ground has been thoronghly loosened and mellowed in the preparation for planting so that in many cases fairly satisfactory growth is secured with a minimum. of cultivation. In the ratoons the soil has been compacted by the trampling of men and teams in getting of the crop and it is of urgent importance to restore it as soon as possible to a condition of mellowness and good tilth. The practice shonld be much the same with either of the systems of planting. First line the trash in alternate middles and let it lie there as a muleh throughout the season. This reduces the area to be cultivated by one half. The expense of transferring the trash and working the second middle may usually be avoided since the heary mulch tends to soften and mellow the soil beneatl it. Each row will therefore be mulched on one side and eultivated on the other, thus getting the benefit of hoth. In the case of gran baneo plantings, however, it will be necessary to at first line the trash in the ditehes and later transfer it to the top of the bank after that has been thoroughly pulverized. As soon as possible after lining the trash and before much nêtw root growth has started, "bar off" each side of the cleaned middle witl a 10-inch ploy running as close to the cane as possible and throwing the dirt toward the middle. In the furrow thas formed put in the first application of fertilizer. On most soils it will be best, 
to mix this in the soil by passing a subsoil flow to stir and open up the soil still more deeply. This should be immediately followed by the harrow-eultivator to pulverize the furrow sluices that have been thrown out and to partially fill the furrows and cover the fertilizer. After this the work will be about the same as in plant eane. An implement of one kind or the other should be passed every ten days or two weeks until the cane closes. The main point is to see that it is passed quickly enough after each heary rain to prevent baking and the forming of a heavy crust that will impede aeration.

The expense of the method of eultivation here outlined will be lat little if any greater than at present since it will save the larger part of the hoe work. It will largely increase yields and will make possible the taking of many more ratoon crops than at present. Above all, nine-tenths of the present losses from root rot will be avoided. Try it out carefully, gentlemen, and see the results for yourselves. 